Journal of the Bangladesh Association of Young Researchers (JBAYR), Volume 1, Number 1, January 2011, Page 93-107

ISSN 1991-0746 (Print), ISSN 2220-119X (Online), DOI:10.3329/jbayr.v1i1.6841

\section{STRUCTURE, DECORATION AND MATERIALS: MUGHAL MOSQUES OF MEDIEVAL DHAKA}

\section{A.T.M. Shamsuzzoha and Hamidul Islam}

Department of Islamic History \& Culture, University of Dhaka, Dhaka-1000 and Department of Islamic History \& Culture, Shahzadpur Govt. College, Sirajgong.

E-mail: babu_416@yahoo.com, hamiddu.edu@gmail.com

\section{ABSTRACT}

Muslim architecture has been initiated from the very beginning of Islamic heritage which is started by the mosque, introduced by Prophet Muhammad (Sm.). From the early age of Islam, Muslim architecture has been developed from the foot point of mosque. Gradually by the expansion of Islam it was circulated in various countries of the world. Later stage, mosque architecture has been introduced into India at the very beginning of $13^{\text {th }}$ century. Mosque architecture in medieval time exposes clearly its sacred identity but in secular architecture, the ideas are not spiritually motivated in cosmic sense. Certainly structural idea, materials and its functionality played a vital role in that era and beyond. Functionality, aesthetic use of materials and technique with effective manner are depending on assimilated technologies. Besides these, integrated process of standard materials, skilled labor, innovative idea and socio-economic as well as geographical factors are important for building any magnificent architecture. Mughal mosques of Dhaka are the unique example of architecture where the ideas and used materials have been effectively amalgamated in the medieval context of Bengal. The present study is an attempt to analyze the structure, structural decoration and use of materials of medieval Mughal Mosques of Dhaka. The study will also cover exclusively interior and exterior structure and design of the mosques. The focus of the study is to demonstrate the effective use of available materials, for representing own belief and cultural exclusivity to the architecture.

KEYWORDS: Structure, decoration, materials, medieval Dhaka, Mughal Mosque, Muslim architecture.

\section{PROLOGUE}

Structure and use of architectural materials in subsequent construction of architectural tradition depends on the socio-economic background of the nation. The idea of architectural tradition is highly influenced by the availability of architectural and design materials for construction and economic strength. National identity and other cultural factors also influence to edifice magnificent architecture. Architectural traditions and by its interpretation essentially depend on structural ideas and materials e.g. bricks, stone, timber, lime etc. On the other hand, structural ideas and its innovative exclusivity may regard to understanding the uniqueness of the architecture. This article is an attempt to analyze the structure, structural decoration and materials of Mughal Mosques of medieval Dhaka ${ }^{1}$ and emphasis in this regard, has been given on exclusively interior and exterior structure and decoration of the mosque.

The mosque constitutes one of the most highly developed forms of religious architecture. With the rapid expansion of the Muslim community through conquests as well as missionary activities, it became necessary to set aside an enclosed area in cities or large towns for the purpose of established communal worship. (Wilber, 1936, p. 250) Mosque architecture in medieval time exposes clearly its sacred identity, even it is continuously remarked, but in secular architecture, the ideas are not spiritually motivated in cosmic sense. Definitely a structural idea and use of materials as well as its functional and aesthetic use play role in determining what is expressed by it. Development of understanding of functional and aesthetic use of materials and technique with effective manner are depending on assimilated technologies. Integrated process of standard materials, skilled labor, innovative idea and socio-economic as well as geographical factors may regard to construct any magnificent architecture.

The evolution of Indo- Muslim architecture in the $12^{\text {th }}$ and the $13^{\text {th }}$ centuries may be described as a synthetic process: the impact of Islam in India was overwhelming, but this does not negatively influenced the Indian architectural skill on the formation of a truly distinctive style of Islamic architecture in India (Asher, 1984, pp. 203-204). The Muslims brought with them their own architectural skill and traditions. They, however, found a completely different environment in India, to which their traditions of architecture had to be accommodated (Hasan, 1971, p.37). The architectural traditions in India during the medieval period were vertical 
and horizontal, which was mastering to formulate structural ideas by both the Hindu and the Muslims. The Mughal followed the homogeneous style which followed in the Sultani mosque. The buildings of the Mughal period show the powerful influence of the Delhi style (Hasan, 2007, p. 3). In context of structure, Mughal mosques of Dhaka are the existing example of gradual transformation of the foreign elements to the taste of local concept and tradition. Abroad architectural ideas imported into India, particularly religious one, dominated by the mosques, from Persia and central Arabia (Hasan, 1971, p. 207). The impact of foreign construction and design technique, successive use of materials and adaptability of ideas with domestic existing theme are the main focal point of this article. Here Indian and traditional Muslim architecture exclusively interior and exterior structure of the mosque will be studied. This is for the first time an effort has been made to look for the structural design as well as materials of the Mughal mosques of Dhaka. It is hoped that this study will trigger more research on medieval mosques of Dhaka in future.

\section{OBJECTIVES OF THE STUDY}

The main objective of the study is to explore and compare the structural design, decorations as well as materials of the medieval Mughal mosques of Dhaka with some leading mosques of the great Mughals. The objective also includes finding out the influences of the structure, decoration and materials of Mughal mosques of Dhaka on the contemporary and modern Muslim structure of Bengal.

\section{SCOPE OF THE STUDY}

This study covers the structure, decorations and materials of the Mughal mosques of Dhaka and its related aspects. In this study, the authors of this paper tried to find out the influences of the structural design and its ornamentations on contemporary and subsequent mosque structure of Bengal.

\section{LIMITATION OF THE STUDY}

This study should not be considered as the comprehensive study of the structure, decoration and materials of the medieval Mughal mosques of Dhaka. The authors only include the Mughal mosques which exist in Dhaka city corporation area for this study. However, the authors tried to make it research worthy and valuable.

\section{METHODOLOGY}

At the inception of the study, a methodology for it was formulated. To ensure quality of the study and compiled documentation the authors followed the methodology of Fielden (1979). A field survey was conducted by the authors on that selected Mughal Mosques of Dhaka. This study concentrates on the structure, decoration and materials of the mosques established during the Mughal period in Dhaka. In selecting the mosque the authors selected almost all the Mughal mosque in Dhaka having precious and research worthy structure, decoration and materials. Several field visits have been conducted by the authors to examine the structure and decorations as well as the materials. A good number of photographs of the structure of Mughal mosques of Dhaka have been taken by the authors for the study. Some of these have been presented in this paper. Some secondary sources e.g. books, journal articles, encyclopedias; photographs have been consulted for this study.

\section{STRUCTURAL DESIGN OF THE MUGHAL MOSQUES OF DHAKA}

The mosque architecture of Dhaka is a unique example which has different architectural qualities. The existing famous mosques of Dhaka survive across the city are, Lalbag Fort Mosque (1649 A.D.), Khawaja Ambar Mosque(c.1680 A.D.), Kar Talab Khan's Mosque (1701-04 A.D.), Khan Muhammad Mirdha's Mosque (1706 A.D.), Haji Khwaja Shahbaz Mosque (1679 A.D.), Satgumbad Mosque (c.1680 A.D.) and Musa Khan' Mosque $\left(18^{\text {th }}\right.$ century). The unique features of these mosques are that, they have perfect space and different structural ideas. The structure chosen for the application of traditional idea with both functional and aesthetic decorations are the mihrab, ${ }^{2}$ the cornice, façade and the panels of interior and exterior walls. The foundations of the Mughal mosques of Dhaka are quite functional which are based on mathematical measurement. Today three-dome, five-domed, seven-domed or multi-domed type of mosques have been seen. Ground plan and interior structure are also differentiating character of these mosques. On the basis of ground plan Mughal mosques of Dhaka are true Bengali type (Dani, 1961, pp. 21-22). Bengali types of mosque characters are seen either as a square or rectangular structure with short size octagonal corner minarets but not have open court. Liwans and tall minarets are being treated as the striking features of the mosque architecture of Dhaka, like the Central Islamic land and Persian traditions. 
The Mughal mosques of Dhaka are mostly in three-domed structure which built on roofed over by three fluted shoulder domes, resting on octagonal drums (Figure-01). Of the three hemispherical domes cover the mosque, of which the central one is bigger than the side ones. These are not equal in height and width. The main prayer chamber of Lalbag Fort Mosque, Haji Khwaja Shahbaz Mosque, Satgumbad Mosque etc. are covered with three fluted shoulder domes resting on octagonal drums, but Kar Talab Khan's Mosque (Figure-02) has five-domes. To cover the smaller bays with the domes, a unique technique has been restored to a half dome on the sides as an intermediary stage, on actual dome springs on a further series of pendentives (Dani, 1961, p. 7). There are three mihrabs inside the western wall in line with the three entrances, three domes, of which the central one is bigger than the side ones. Rectangular plan with octagonal corner minaret, pendentives have been used in their phase of transition. These are commonly seen in Dhaka like Lalbag Fort Mosque, Khan Muhammad Mirdha's Mosque, Haji Khwaja Shahbaz Mosque, Satgumbad Mosque etc. Most of the Mughal Mosque of Dhaka are consists corner tower with flanking turrets like those in Saitgumbad Mosque, Khawaja Shahbaz Mosque and Musa Khan Mosque. Each of these consists of two storeys and in an amount by itself is a distinctive feature (Banglapedia, vol.9, 2003, p. 96).

The using plans including single-aisled, three-bayed, rectangular type are the systematic process of focused in these mosques. The faceted recessed arches of the central entrance of Lalbag Fort Mosque are also seen on the nearby Bara Katra and the contemporary mosques of Rajmahal (Asher, 1984 , p. 200). Its cusped arches and rows of recessed niches give this single-aisled three- bayed mosque of a refined quality than those in contemporary Rajmahal. In spite of its fluted domes, an eighteenthcentury restoration, it remains the best example of the fully mature Mughal mosque-type of this period in Bengal. The main entrance of the Lalbag Fort Mosque opens under a half-dome, the under-side of which is decorated with plastered net-work. Interior space of the mosque is reduced into three bays in different measurement by two lateral arches. The bays of both sides are smaller in width, but covering the smaller bays with half domes as an intermediary stage (Dani, 1961, p. 7).

The ground plan of the Lalbag Fort Mosque site is an example of space perfection. It consists of rectangular ground plan with four regular octagonal corner Minars. Similar plan has been found in the Haji Khwaja Shahbaz Mosques as well as the Satgumbad Mosque (Figure-03). Three unequal rectangular door ways and three mihrabs are projected at qibla wall with half-octagonal shapes. Central mihrab is bigger than the central door ways and the domes. The prayer chamber is divided into three bays, central one is square shaped and north and southern bays are rectangular in shapes which are same as other Mughal mosques of Dhaka, e.g. Khan Muhammad Mirdha's Mosque (Figure-05 and 06), Haji Khwaja Shahbaz Mosque (Figure-04) are followed by the same structure. But the mihrab of Satgumbad Mosque is deeper than other mosques of Dhaka. The ground plan of the Kar Talab Khan's Mosque, Khan Muhammad Mirdha's Mosque is different at ground level. These are standing on more than sixteen feet high platform above the ground level underneath which are vaulted rooms. Every mosque has north and southern doorways building with rectangular plan.

Khan Muhammad Mirdh's Mosque is one of a number of mosques in Mughal Dhaka which have been constructed on a vaulted podium. Kar Talab Khan's Mosque in begum Bazar is its harbinger (Architectural Conservation Bangladesh, 1993, p.140). Succeeding examples in the city includes Natun Paltan Mosque (1708) of west Azimpur, Chowdhury Bazar Mosque (1719) and Yatim Khana Mosque (1723) of Lalbagh Road and Siddiq Bazar Mosque (1913) of Fulbaria station etc.

\section{ARCHITECTURAL DECORATION}

In interior decoration, the mosque architecture of Dhaka has shown special emphasis on the mihrab and qibla wall in all over the Islamic architectural formation of the world. For the formal ceremony of prayer Salatul zumua, the Imam stands in front of the believers near mihrab, indicating the direction of prayer. The mihrab, mimbar ${ }^{3}$ become the symbol of legal authority in the place of worship though in designing the mimbar has shown special features in Mughal Bengal. The eastern façade of the Lalbag Fort Mosque, Satgumbad Mosque, Kar Talab Khan's Mosque, Musa Khan's mosque are well decorated with rectangular panels containing multi foiled arches in the usual Mughal Style with the central arched doorways are receiving prominent than the side doorways. The façade of Haji Khwaja Shahbaz Mosque shows the usual projection of the surface in the middle through which opens the middle doorways filled with stone arch-frame. On the both sides of the middle door can be seen five rows of the niches. There are two more arched entrances on this side. Southern and northern façade of this mosque as well as its interior have also been ornamented by 
panel decoration. In building decoration, the Kartalab Khan Mosque has flanking ornamental turrets of the doorway and mihrab projections, kiosks, cupolas, and lotus kalasa finial which gave its beautiful decorative identity (Banglapedia, vol.6, 2003, p. 27).

Two of the most important components of the mosques, the dome and minaret, were constructed according to centralized plans using traditional measurement system in the Mughal Mosques of Dhaka. Octagonal corner minarets shooting above the parapet wall with their plastered kiosks seen in the Lalbag Fort Mosque. Similarly the corner minaret of the Kar Talab Khan's Mosque has followed this style. The corner minarets of the Satgumbad Mosque (Figure-07) are hollow and built in two stages with covering of domes. But the corner minarets of the Haji Khwaja Shahbaz Mosque are two shapes as octagonal to the height of the parapet and rounded upwards and having ribbed cupolas on the top, similarly with the corner minarets of the Khan Muhammad Mirdha's Mosque. In plan and decoration, minarets have circular or polygonal outlines and in some case a combination of both circular and polygonal outlines had been shown in the Mughal Mosque as well as rest of the Islamic world. Perfect geometric shapes had been applied in the mosques of Dhaka building minarets though these are not taller than the Mughal mosque, the architecture of Northern India.

But the domes of Khan Muhammad Mirdha's Mosque are different from other Mughal mosques of Dhaka in context of the size of the side domes and using technique. The domes have basal leaf, decorating in geometric forms like diamond, triangular shapes and are crowned tall finials in step by step. Considerable experimentations in three-dimensional application of geometry also took place in the transitional zone of the dome. The use of the traditional devices of squench and pendentives, as inherited from pre-Islamic architectural traditions, was continued and also elaborated upon by the Muslims (Al- Asad, 1994, p. 65).

In decoration, complicated geometrical patterns, arabesque designs consisting of vegetal motifs, Arabic and Persian calligraphy are frequently used. On the other hand, glazed tiles, colorful mosaics, smooth terracotta (Figure-08) are used occasionally. In the Islamic Architectural concept, formulas and rules of geometry were applied to meet both functional and aesthetical purposes in a flexible manner. The application of geometric formulas in the interior and exterior decoration of the mosques of Dhaka has been seen (Figure-09 and 10). Salient portions of their architecture such as mihrab, mimber, domes, arches, and decorative muqarnas are designed and built on applying the local techniques with skilled hand. The mihrab, quibla wall as well as façade are ornamented by the frequent use of plaster but terracotta and stucco (Figure-11, 12, 13 \& 14) use occasionally (Banglapedia, vol.7, 2003, p. 88). The motifs of the decoration are organized two-dimensional decorative patterns consisted not only abstract geometric shapes but also included vegetal designs. Lalbag Fort Mosque, Khan Muhammad Mirdha's Mosque, Haji Khwaja Shahbaz Mosque's mihrabs are ornamented with smooth terracotta floral and geometric ornaments. There are lotus insides, rosettes, leaves and brides In the spaces between the stages occurred a frieze of diamond and triangular shapes. The edges of the successive stages of different places are decorated with different shapes of vegetal motifs. Various exclusive application of calligraphic effect of monotony have been shown in the Mughal mosques of Dhaka, which are different from other decorative features of the Islamic world originated from native motifs.

\section{ARCHITECTURAL MATERIALS}

Architectural materials including bricks, sand, lime used in the Mughal Mosques of Dhaka, which are plain by plaster. Plastered wall are some of the typical features of Mughal architecture of Bengal (Hasan, 1983, p.146). Due to lack of easy availability of architectural material like stone within the short distance, the Mughal mosque continued to be dominated by brick masonry in its building art and they moulded terracotta made out of the fine textured alluvial clay for purposes of surface decoration. Bengal architecture, exclusively mosque, in ornamentation and structuring bricks are used as principal materials like Persian architecture. The tradition of brick building in Bengal was a more continuation of the process of brick architecture of Persia, which penetrated Bengal through Gujrat, the Daccan and others brick building channels (Hasan, 1980, p. 205). Brick thus lends Bengal architecture a style which is distinct, with its pointed arches and finishes so different from those in stone.

Decorative patterns, aesthetic quality depended on architectural materials which are used in structuring the architecture like bricks, sand, lime etc The composition of lime, masonry and sand has been used as a plaster on the surface of the interior and exterior wall, roof and domes in order to make the construction smooth and water-tight. Though the Sultani 
Mosques of Bengal have unique exposition of surface decoration including stone-cut design, terracotta, color marble and pleasuring ornamentation but the Mughal mosques are simply ornamented by plaster in different style as rectangle and arched panels, flat, four-centered or multi-foiled arches. Due to lack of easy availability of architectural material like stone within the short distance, the Mughal mosque continued to be dominated by brick masonry in its building art and the moulded terracotta made out of the fine textured alluvial clay for purposes of surface decoration (Ahmed, 1984, pp. 166-181). The quibla wall has elegantly decorated by mihrabs and usual panel designs. In this context, use of mihrabs in the mosques is the aesthetic symbol.

The Muslim architecture that developed in Bengal, had an individuality of its own, and it bears a definite stamps of this deltaic land. Effective use of available materials in both structuring and decoration, Islamic architecture of Bengal has shown mastering like other regional characteristics. Using of Persian color tile work and Damascus golden mosaics are exposed glory of Bengal architecture. In contrast to the green and golden mosaics of Jerusalem and Damascus, or the superb coloring of Persian tile work, or the wonderful fantasies of Spanish design, Bengal offers her marvelous art design in terracotta that take their inspiration from the jungle scene of this land (Dani, 1961, P. 7). Though plaster was widely used on the surface of the walls as well, but from the very beginning of the $15^{\text {th }}$ century we find the use of glazed tiles in Bengal as well as at Dhaka. They are used in both in mono colour as well as in polychrome. Some of them bear floral decorations on them. The manner in which different glazed tiles play a definite part in the design proves that they were manufactured locally (Dani, 1961, p. 12). Very few stone or timber used in the mosques of Dhaka, not for basic structure, but to ornament and functional use in door and windows in timber and stone in mihrab for emphasis on the magnificence of the structural identity. Majority of the brick structures are depended upon wood for their internal support while stones are used in writing inscriptions, solid mimber occasionally in steer case. Stone had been used in door-frames and pillars for fashion materials (Saraswati, 1976, p. 7). The east arch, pulpit and Mihrab of Khawaja Ambar Mosque are also framed in Rajmahal black basalt stone (Figure-15 and 16) which is a unique feature of the using of materials of the Mughal Mosques of Dhaka (Ahmed, 1984, p. 177).

\section{CONCLUSION}

From the aforesaid discussion it is apparent that the Muslim architecture developed in Bengal, had an individuality of its own, and it bears definite stamps of this deltaic land. The Mosque architecture of Mughal Dhaka undoubtedly made a profound contribution to the history of world architecture in general and particularly in Indo-Muslim architecture. Mughal Mosques of Dhaka influenced later Muslim and Non-Muslim architecture of Bengal structurally and by various designs. The system of plastered walls and the construction of the dome are followed subsequent structures of Dhaka. Chawk Masjid, Jinjira Palace, Hosni Dalan etc. are examples. The carved brick decoration, wall paneling system, three dome and commonly used single dome system influenced later structures. Star Mosque of Armanitola ( $1^{\text {st }}$ half of $19^{\text {th }}$ century), Parulia Mosque of Narshindhi district, Bajra Shahi Mosque (1741- 44 A.D.) of Noakhli, Bara Jamalpur Mosque (c. mid $18^{\text {th }}$ century) of Gaibandha etc. are living examples. These features are now also traced in the various buildings found in the different parts of Bengal. The Mughal Mosques of Dhaka also influenced later architecture of Bengal by its interior structural design and the use of materials. Its structure and decoration on the basis of materials merits and mathematical measurement is unique. The use of bricks, masonry and lime, different types of stone, terracotta and mosaic decorate its interior heavily. Its complicated geometrical patterns, arabesque designs consisting of vegetal motifs, Arabic and Persian calligraphy influenced later Muslim and non-Muslim architecture a lot. So it is easy to determine that, the assimilation of materials and structural ideas of the Mughal Mosque of Dhaka have played a vital role in the functional and aesthetical development of Islamic architecture of Bengal.

\section{NOTES}

1 Mediaeval Dhaka means the time frame of (1576-1717 C.E.). It indicates mainly the direct rule of the Great Mughals in Bengal.

2 Mihrab meaning "the place of the lance". It symbolized the place where Prophet (pbuh) stood in the first mosque of Medina.

3 Mimbar is that place from where Imam pronounces the khutbah, commonly known as pulpit. 


\section{REFERENCES}

Ahmed, N. (1984). Discover the monuments of Bangladesh: A Guide to their history, location \& development. Ed. by John Sendey, UNESCO: Dhaka.

Al- Asad, M. (1994). Application of geometry; The mosque, London: Thames and Hudson.

Asher, C. B. (1984), The Mughal and post-Mughal periods in George Michell (ed.) The Islamic heritage of Bengal. Paris.

Asiatic Society of Bangladesh, (1993). Architectural conservation Bangladesh. Ed. by Abu H. I mamuddin. Dhaka.

Banglapedia, vols. 6, 7, 9 (2003). Ed. by Sirajul Islam. Asiatic Society of Bangladesh, Dhaka.

Dani, A. H. (1961). Muslim architecture in Bengal. Dacca: Asiatic Society of Pakistan.

Hasan, P. (2007). Sultans and mosques; The early Muslim architecture of Bangladesh, London: I.B.Tauris \& Co.

Hasan, S. M. (1980). Muslim monuments of Bangladesh, $2^{\text {nd }}$ edition, Dacca: Islamic Foundation of Bangladesh.

Hasan, S. M. (1971). Mosque architecture of pre-Mughal Bengal. The academy for Pakistan affairs, Dhaka.

Hasan, S. M. (1983), Glimpses of Muslim Art and Architecture, Islamic Foundation of Bangladesh, Dhaka.

Saraswati, S.K. (1976). Architecture of Bengal, Book. Calcutta: 1, G. Bharadwaj \& Co.

Wilber, D.B. (1936). The religious edifice and community life in muslin world, vol.xxvi, No. 3. London.

A.T.M. Shamuszzoha and Hamidul Islam

APPENDIX

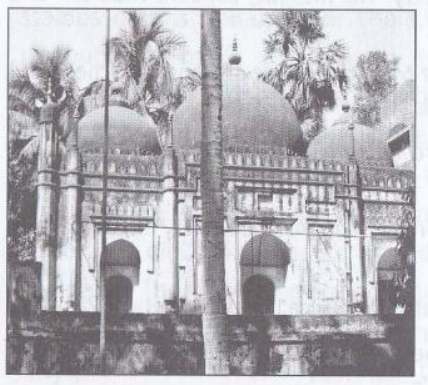

Figure-01 Three dome structure of Musa Khan Mosque

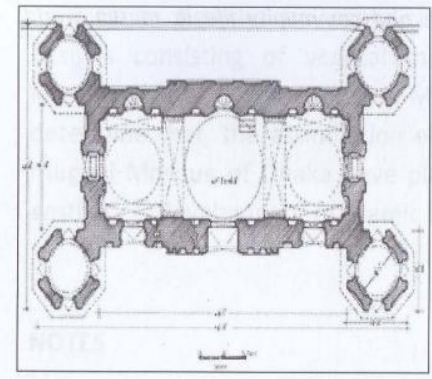

Figure-03 Ground plan of Satgumbad Mosque, source: Banglapedia

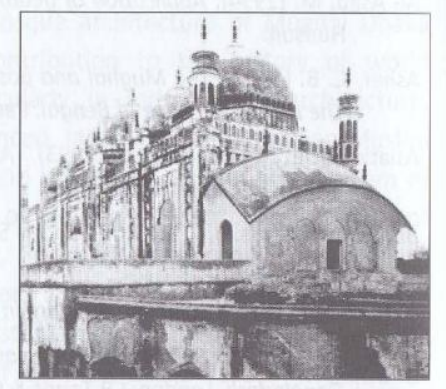

Figure-02 Kartalab Mosque, Source: Banglapedia

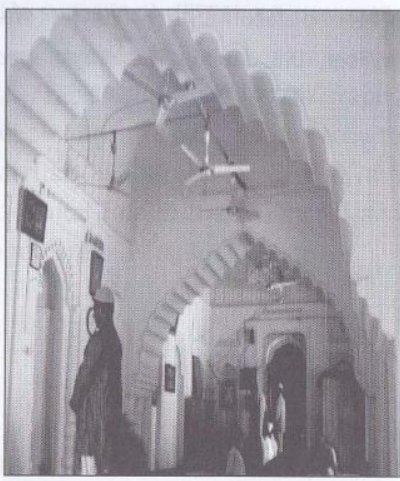

Figure-04 Prayer chamber of Haji Khawaja Shabaz Mosque 
Structure, Decoration and Materials: Mughal Mơsques of Medieval Dhaka
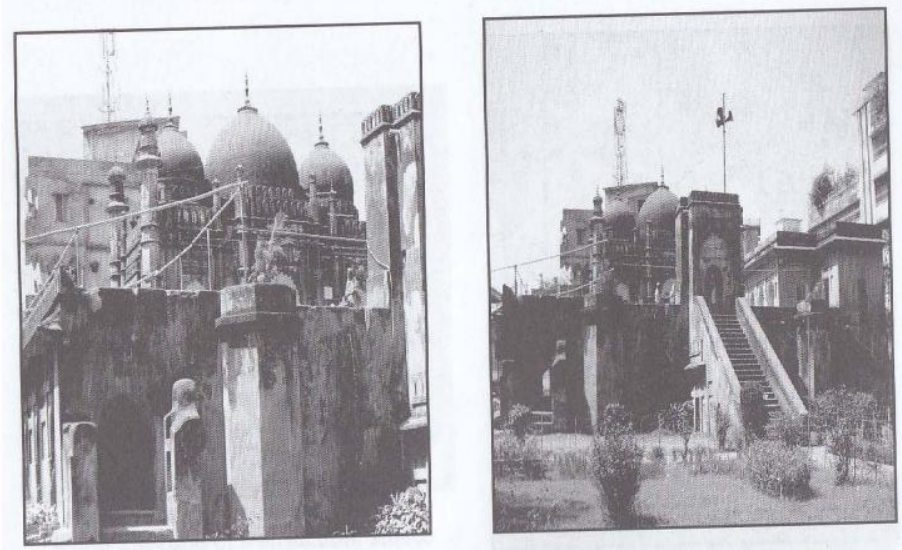

Figure- 05 \& 06 The exterior and central chamber of Khan Muhammad Mirdha'sMosque

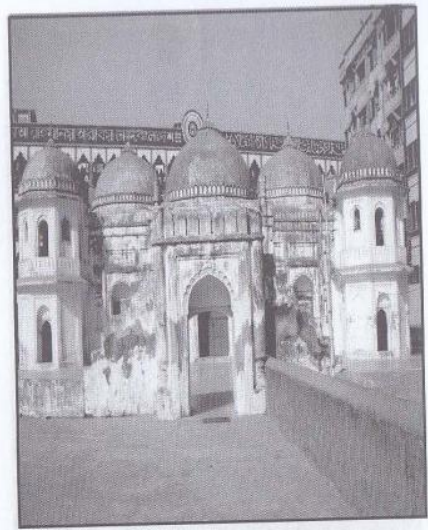

Figure-07 Saitgumbad Mosque

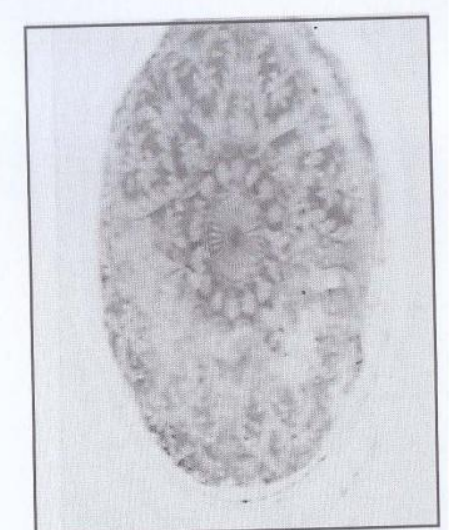

Figure-08 Terracotta, Khan Muhammad Mirdha's Mosques

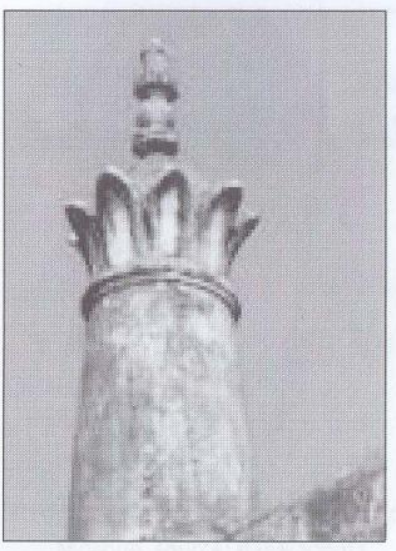

Figure- 11 Top pieer, geometrical stucco design of Khawaja Shahbaz Mosque

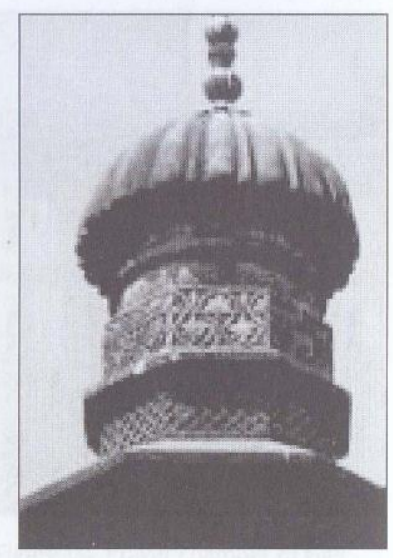

Figure-12. Stucco design, Khan Muhammad Mirdha Mosque 
Structure, Decoration and Materials: Mughal Masques of Medieval Dhaka

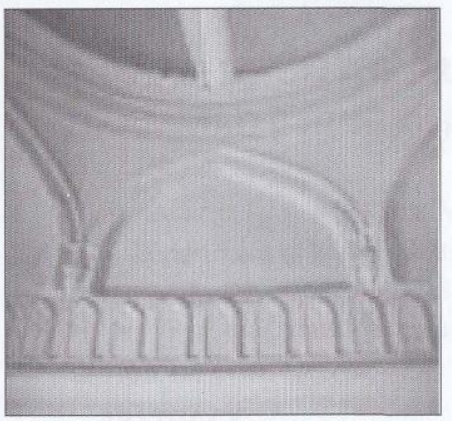

Figure- 13 Zone of transaction, stucco design, Satgumbad Mosque

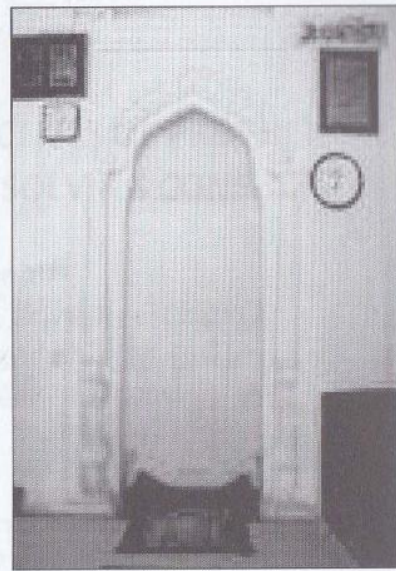

Figure- 14 Stucco design, Mihrab Satgumbad Mosque
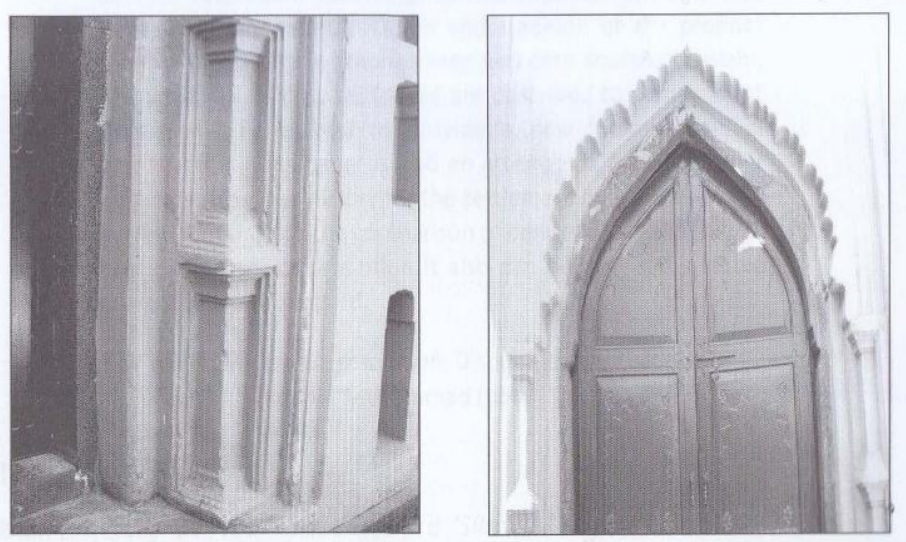

Figure-15 \& 16 Use of black stone at Haji Khawaja Shahbaz Mosques 